ELORE (ISSN 1456-3010), vol. 18 - 1/2011.

Julkaisija: Suomen Kansantietouden Tutkijain Seura ry. [http://www.elore.fi/arkisto/1_11/kirjat_keinanen.pdf]

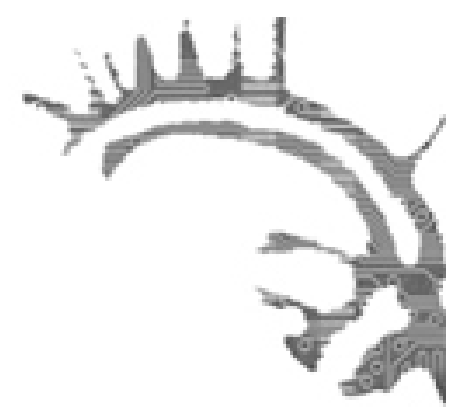

KIRJA-ARVIO

\title{
2000-LUVUN NÄKÖKULMIA POHJOISVIENALAISEN \\ Marina Takalon matkaAn runOnlaUlajaKsi ja NÄKIJÄKSI
}

PENTIKÄINEN, JUHA 2010: Marina Takalo. Runonlaulaja ja näkijä. Suomalaisen Kirjallisuuden Seuran Toimituksia 1270. Helsinki: SKS. 490 sivua.

\section{Marja-Liisa Keinänen}

Professori Juha Pentikäinen on luonnehtinut viiden vuosikymmenen pituista työrupeamaansa Marina Takalo -tutkimuksen parissa kolmivaiheiseksi prosessiksi. Prosessin ensimmäinen vaihe alkoi kesällä 1960 nuoren opiskelijapojan tavatessa Kuusamossa runonlaulajana esiintyneen, pohjoisvienalaista alkuperää olleen Marina Takalon. Tämä tapaaminen johti pitkäaikaiseen yhteistyöhön, jonka tuloksena ilmestyi yksitoista vuotta myöhemmin jo klassikoksi muodostunut kirja, Marina Takalon uskonto. Uskontoantropologinen tutkimus. Koska tämä Pentikäisen jo ylioppilasaikanaan aloittama tutkimus ei kuitenkaan kelvannut väitöskirjan aiheeksi 1960-luvulla, Marina Takalon uskonto -kirja jäi väitelleen tutkijan kypsyysnäytteeksi.

Prosessin seuraava vaihe oli kirjan vuonna 1978 ilmestynyt englanninkielinen versio, Oral Repertoire and World View: An Anthropological Study of Marina Takalo's Life History, josta otettiin myös uusintapainos vuonna 1987. Käsillä oleva peräti 490-sivuinen uudelleen työstetty teos Marina Takalo: Runonlaulaja ja näkijä -kirja on tämän pitkän prosessin kolmas merkkipaalu. Tuntien kirjoittajan dynaamisuuden tutkijana kirjaa uskaltaa tuskin luonnehtia Marina Takalo -tutkimuksen tilinpäätökseksi, sillä aiheelle on todennäköisesti tulossa jatkoa muodossa tai toisessa. Kirjaa voi kuitenkin pitää eräänlaisena välitilinpäätöksenä, sillä tutkija summaa siinä pitkää tutkimusprosessiaan ja yhteistyötään Takalon ja tämän perheenjäsenten kanssa. Sitä voi pitää myös eräänlaisena juhlakirjana, tulihan vuonna 2010 kuluneeksi 130 vuotta Takalon synty- 
mästä, 40 vuotta hänen kuolemastaan ja viisi vuosikymmentä Takalon ja Pentikäisen ensitapaamisesta.

\section{Pohjoisvienalaisen Kansanuskon ja -HuRskauden TUTKIMUKSEN PERUSTEOKSET}

Marina Takalon uskonto -teosta ja sen englanninkielistä laitosta voidaan pitää monessa suhteessa uraauurtavana. Kirjoittaja määrittelee työnsä uskontoantropologiseksi yksilötutkimukseksi, mikä merkitsee sitä, että se kohdistuu Takaloon uskonnollisena ihmisenä. Toisin kuin aikaisemmassa folkloretutkimuksessa, jonka painopiste on ollut "loressa", Pentikäinen ottaa lähtökohdakseen kansan ('folk"), toisin sanoen ihmisen perinteenkantajana, -tuottajana ja perinnettä kommunikoivana sosiaalisena yksilönä. Antropologisuus merkitsee myös sitä, että tutkija lähestyy kohdettaan holistisesti, tarkastellen sitä kulttuurisessa ja ekologisessa kontekstissaan.

Pentikäisen ensimmäinen Takalo-tutkimus pohjautuu pitkäaikaiseen ja systemaattiseen haastattelutyöhön, ja sen kunnianhimoisena päämääränä oli Takalon koko uskonnollisen perinnerepertuaarin tallentaminen ja hänen maailmankuvansa rekonstruoiminen tämän aineiston pohjalta. Aikansa tyylin mukaisesti työn jäsentely ankkuroitui vahvasti perinnelajianalyysiin uskontoa tuottavan ihmisen pysyessä kuitenkin tutkimuksen keskiössä.

Vaikka Marina Takalon uskonto -kirjan ilmestymisestä on kulunut jo neljäkymmentä vuotta, kuuluu se ja sen laajennettu englanninkielinen versio edelleen ortodoksisen Karjalan kansanuskoa ja kansanhurskautta käsitteleviin perusteoksiin. Teokset ovat perusteellisuutensa ja järjestelmällisen lähestymistapansa vuoksi toimineet ainakin itselleni myös pohjoisvienalaisen kansanuskon ja -hurskauden käsikirjoina, koska ne pyrkivät suhteuttamaan Takalolta kerätyt tiedot myös laajempaan vienalaiseen kontekstiin.

Marina Takalon uskonto valottaa Takalon uskonnollisuuden eri ulottuvuuksia ja hänen suulliseen perinteeseen perustuvan uskonnollisuutensa muovautumista. Tärkeä lähde on hänen omaelämänkerrallinen runoutensa, jonka kautta kirjoittaja hahmottaa myös Takalon maailmankatsomusta. Kirja antaa ainutlaatuista tietoa pohjoisvienalaisesta vanhauskoisuudesta edellisen vuosisadan vaihteessa, mutta on samalla kattava esitys paikallisesta rituaaliperinteestä. Teos tekee perusteellisesti selkoa vienalaisesta tietäjälaitoksesta ja kuvaa tietäjän rituaalista toimintaa sekä tätä toimintaa ohjanneita uskomuksia ja sairauskäsityksiä. Kirja antaa kattavan esityksen myös pohjoisvienalaisesta haltijamaailmasta sekä muista supranormaaleista olennoista.

Kirjan kahden aikaisemman laitoksen pääasiallisena kohdeyleisönä on ollut tutkijayhteisö, mutta uusin versio avautuu myös suurelle yleisölle. Kirjaa voidaan pitää populaarina, koska siitä on karsittu edellisten versioiden painavat teoriaosat, eikä kirja pyri ilmaisultaan samaan tieteelliseen tarkkuuteen kuin edeltäjänsä. Sen leipätekstistä puuttuu myös viitteistö, mutta lopusta löytyy kuitenkin täydennetty lähdeluettelo. Kirjalla on tieteellisiäkin tavoitteita, sillä se pyrkii tarkentamaan perinnelajianalyysiä nostamalla esiin eemisiä, "kotoperäisiä" kategorioita. Kirjaa on myös täydennetty uu- 
della aineistolla, esimerkiksi saduilla, kehtolauluilla ja autobiografisilla runoilla. Osa näistä aineistoista karsiutui edellisistä editioista, joiden nimenomaisena päämääränä oli uskonnon kartoitus. Myös uutta kiinnostavaa kuva-aineistoa on lisätty, samoin uusia nuotinnuksia. Kirjan historiallisesti tärkeänä antina voidaan pitää pakolaisnaisen ja hänen perheensä elinehtojen kuvausta 1900-luvun Suomessa.

\section{Marina TAKalon USKONNON UUDELLEEN LUKUA}

Käsillä olevassa teoksessa Takalon henkilökuva on rikastunut, mutta samalla komplisoitunut, koska kirjoittaja valottaa sitä myös Marinan lapsilta, tutuilta ja naapureilta myöhemmin keräämänsä haastatteluaineiston pohjalta. Niin ikään Takalon pohjoisvienalaisen elinympäristön kuvaus on syventynyt. Korostamalla pohjoisvienalaisten liikkuvuutta ja alueen monikulttuurisuutta Pentikäinen rikkoo myyttiä Vienan Karjalasta reliktialueena, joka syrjäisen sijaintinsa vuoksi pysyi ulkopuolisten vaikutusten ulottumattomissa ja tästä syystä kykeni säilyttämään arkaaista perinnettä jälkipolville.

Koska Marina Takalo: Runonlaulaja ja näkijä-kirjaa voidaan pitää ensimmäisen kirjan populaarina versiona, ei sille luonnollisestikaan voida asettaa tieteellisen tutkimuksen vaatimuksia esimerkiksi tutkimuskirjallisuuden päivityksen suhteen. Tämäntyyppinen päivitystyö olisi ollut varsin vaativa tehtävä, sillä uskonnon ja folkloren tutkimushan on edennyt jättiläisharppauksin viimeisen neljän vuosikymmenen aikana, ja karjalaista kansanuskoa koskevaa uutta kirjallisuutta on julkaistu sangen runsaasti. Julkaisun kirjallisuusluettelo jää siis uudemman kirjallisuuden osalta suppeahkoksi. Koska kirjoittaja on kaikesta huolimatta käyttänyt uuttakin tutkimuskirjallisuutta, pidän oikeutettuna kommentoida kirjallisuuslistan joitakin puutteita. Koska Takalo-kirjojen heikkoutena on pidetty sitä, että ne perustuvat pitkälti yhdeltä ihmiseltä kerättyyn aineistoon, olisi tutkijalla ollut oiva tilaisuus vahvistaa aikaisempien tutkimustensa luomaa kuvaa Pohjois-Vienan uskonnollisesta kentästä. Pentikäinen on käyttänyt kirjan taustoituksessa ja vertailupohjan luomisessa suomalaisten kerääjien alueelta tallettamaa vanhempaa suullista perinnettä, mutta kuvaa olisi voinut syventää hyödyntämällä esimerkiksi Petroskoin arkiston kokoelmia ja petroskoilaisten tutkijoiden näiden kokoelmien pohjalta tekemää tutkimusta.

Suurelle yleisölle suunnattuna, eräänlaisena juhlakirjana teos on saanut henkilökohtaisemman otteen, mikä on myös mahdollistanut tutkijan esiin astumisen muistelijana. Lukija voi seurata kirjoittajan tutkijanuran alkuaskelia ja tutustua pitkän työprosessin eri vaiheisiin sekä saada tietoa hänen henkilökohtaisesta suhteestaan Takaloon ja tämän perheenjäseniin. Loppukappaleessa voimme seurata myös tutkijan paluuta kentälle Kuusamon Heikkilän kylään, missä tämä prosessi sai alkunsa puoli vuosisataa aikaisemmin.

Kirjan luonne viiden vuosikymmenen pituista tutkimusprosessia luotaavana tilityksenä luo sille vahvan nostalgisen pohjavireen ja Takalon persoona ja hänen pohjoisvienalainen mielenmaisemansa kietoutuvat kirjassa hieman romantisoivaan, jopa eksoottiseen vaippaan. Pentikäisen ensimmäisen kirjan kirjoittamisen jälkeiset tutkimusaiheet ja -painotukset kuultavat selvästi läpi hänen tekstissään ja hän uudel- 
leenlukee aiempaa Marina Takalo uskonto -kirjaansa vanhauskoisuuden, šamanismin ja saamelaisuuden tutkimuksellisten rastereiden läpi. Tämä ilmenee esimerkiksi hänen terminologissa valinnoissaan.

Vanhauskoisuuden tutkimukselle omistautuneena Pentikäinen tulee edelleen ylikorostaneeksi vanhauskoisuuden merkitystä Pohjois-Vienassa. Esimerkkinä vanhauskoisuuden liiallisesta korostamisesta voidaan mainita niïn sanotut räähkäkiellot. Pentikäisen mukaan ne ovat nimenomaisesti vanhauskoisten perinnettä, jotka siirtyivät heiltä paikalliseen kollektiivitraditioon. On kuitenkin ajateltavissa, että monet näistä kielloista olivat alun perin osa kollektiivitraditiota, mutta säilyivät pisimpään konservatiivisuudestaan tunnettujen vanhauskoisten parissa.

\section{RUNONLAULAJAKSI RAKENTUMINEN}

Kirjoittaja lupaa kirjansa alkusanoissa, että "[]ukija voi seurata kuinka luovan ihmisen mielessä syntyy vähitellen Suuri Kertomus. Yhteistyömme tulos on elämän ja kertojansa näköinen, yhden ihmisen muistitiedossa punottu suullinen tarina" (s. 9). Käsillä olevan kirjan yksi päämäärä onkin ollut nostaa kertojan ääni kuuluviin. Tässä tarkoituksessa Pentikäinen on myös kuunnellut uudelleen 1960-luvulla tekemiään nauhoituksia, joita on kertynyt kunnioitettavat sata tuntia. Vaikka tutkija tavoitteleekin kirjassaan refleksiivisyyttä ja on selvästi tietoinen osuudestaan tämän "Suuren Kertomuksen" muodostumisessa, pyrkii kirjan retorinen ote siitä huolimatta redusoimaan tutkijan merkityksen tässä prosessissa.

Korostamalla järjestelmällisesti Takalon luovuutta ja itsenäisyyttä kertojana ja runonlaulajana, kirja häivyttää tutkijoiden roolin runonlaulajan syntyprosessissa. Kirjoittajan kertomus luo kuvaa Takalosta jo "valmiina", asemansa saavuttaneena runonlaulajana, jonka tutkijat "löysivät" 1950-luvun lopulla. Pentikäinen osoittaa, että Takalo oli esiintyjänä luonut kiinteän repertuaarinsa jo ennen tutkijoiden tapaamista. Takalo oli myös hahmotellut häälauluista muistissaan lähes valmiin "eepoksen", jonka hänen poikansa oli lähettänyt Kansanrunousarkistoon. Aktiivisen repertuaarinsa lisäksi Takalolla oli runsas latentti perinne talletettuna muistin eri kerroksiin, josta ne asteittain aktivoituivat hänen ja tutkijan välisen kymmenenvuotisen yhteistyön aikana. Tutkijan tehtäväksi jäi perinteen esiin houkutteleminen aluksi aktiivisena kuuntelijana, mutta myöhemmin myös järjestelmällisenä haastattelijana, sekä perinteen tallentaminen ja siirtäminen kansien väliin.

Kirjan johdanto-osasta voimme kuitenkin seurata, kuinka tutkijat yhdessä rakentavat asteittain luku- ja kirjoitustaidottomasta Takalosta runonlaulajaa. Takalo oli itsekin aktiivinen tässä prosessissa, sillä tarjosihan rooli arvostettuna runonlaulajana syrjitylle pakolaisnaiselle kompensaation mahdollisuuden. Takalon lukutaidottomuutta korostetaankin kirjassa useaan otteeseen, sillä se on tärkeä kriteeri hänen "autenttisuudelle" runonlaulajana. Pentikäisen oppi-isän Martti Haavion Viimeiset runonlaulajat -kirja, jonka kirjoittaja mainitsee itselleen merkitsevänä teoksena, toimi todennäköisesti yhtenä mallina runonlaulajan rakentamisessa. Prosessi eteni nopeasti. Jo heti ensi tapaamisen jälkeen Pentikäinen julkaisi Takalosta artikkelin "Kenttäniemen runon- 
laulaja" ja seuraavana vuonna hän teki radio-ohjelman "Marina Takalo, runonlauluperinteen viimeisiä taitajia". Vuonna 1965 Suomalaisen Kirjallisuuden Seura myönsi Takalolle 1. perinteentaitajan kunniapalkinnon ja pari vuotta myöhemmin hän istui runonlaulajapatsaisiin erikoistuneen kuvanveistäjä Nina Sailon mallina.

Tarkoitukseni ei ole aloittaa keskustelua Takalon autenttisuudesta runonlaulajana, vaan peräänkuulutan refleksiivistä pohdintaa tutkijan merkityksestä prosessissa, joka tuottaa haastateltavasta runonlaulajaa. Esittämäni huomautukset eivät horjuta Marina Takalo -teosten vankkaa asemaa karjalaisen kansanuskon tutkimuksen klassikkoina, ja on hienoa, että tämän uuden laitoksen myötä suurelle yleisölle tarjoutuu mahdollisuus tutustua Takalon välittämänä pohjoisvienalaiseen uskonnolliseen kenttään ja mielenmaisemaan.

\section{KirjallisuUs}

HAAVIO, MARTTI 1943: Viimeiset runonlaulajat. Porvoo: WSOY.

PENTIKÄINEN, JUHA 1971: Marina Takalon uskonto. Uskontoantropologinen tutkimus. Suomalaisen Kirjallisuuden Seuran toimituksia 299. Helsinki: SKS.

PENTIKÄINEN, JUHA 1978: Oral Repertoire and World View. An Antbropological Study of Marina Takalo's Life History. FF Communications 219. Helsinki: Academia Scientiarum Fennica.

Filosofian tohtori, dosentti Marja-Liisa Keinänen on tutkijana Tukholman yliopiston Sukupuolen tutkimuksen laitoksella ja Uppsalan yliopiston Hugo Valentin -keskuksen vähemmistötutkimusyksikössä. 